\title{
Residual study of metamifop 10 Ec in grain, straw and soil in direct seeded rice
}

\begin{abstract}
Field experiment was conducted to evaluate the efficacy of Metamifop in direct seeded rice. The treatments were metamifop at 50,75, 100 and $125 \mathrm{~g}$ a.i ha-1 applied at 2-3 leaf stage of weeds;. Metamifop was also applied at 50,75, 100, 125 and 200g a.i ha-1 at 5-6 leaf stage. The residue of metamifop was determined in soil, grain and straw from plots where it was applied at 200g a.i ha-1 at 5-6 leaf stage (T9) followed by the application of metamifop at $125 \mathrm{~g}$ a.i ha-1 at 5-6 leaf stage (T8) and application of metamifop at 100g a.i ha-1 at 5-6 leaf stage (T7) Decrease in dose decreases the residue content. This might be due to the lesser degradation of the active substance. At the same time, for the same rate of application of $125 \mathrm{~g}$ a.i ha- 1 , the concentration of residue varies with the time of application i.e the mean residue of metamifop at post harvest soil was 0.031 and $0.048 \mathrm{ppm}$ respectively in the plots which received metamifop at 2-3 leaf and 5-6 leaf stage. Application the metamifop at lower dose of 50 and $75 \mathrm{~g}$ a.i ha- 1 did not show any residues i.e non detectable level.
\end{abstract}

Volume 5 Issue 5 - 2016

\author{
Arun venkatesh $\mathrm{S},{ }^{\prime}$ Velayutham $\mathrm{A}^{2}$ \\ 'Assistant Professor, RVS Agricultural College, India \\ 2Department of Agronomy, Tamil Nadu Agricultural University, \\ India \\ Correspondence: Arun Venkatesh K,Assistant Professor, RVS \\ Agricultural College, Thanjavur, India, \\ Email venkatesarun@gmail.com
}

Received: May 31, 2016 | Published: December 28, 2016

\section{Introduction}

Rice is the staple food for more than half of the world's population. In Asia, more than $80 \%$ of the people live on rice, and their primary food security is entirely dependent on the volume of rice produced in this part of the world. However, increase in rice production is now lagging behind population growth. Overall, the total global rice production is declining gradually even with the extensive use of the high yielding modern varieties and hybrids. India is having the rice growing area of 42.63 million ha with a production of 85.72 million tonnes and a productivity of $2,011 \mathrm{~kg} \mathrm{ha}^{-1}$. In Tamil Nadu, rice is cultivated in an area of 1.93 million ha with a production of 6.61 million tonnes and a productivity of $3,423 \mathrm{~kg} \mathrm{ha}^{-1} .{ }^{1}$ Direct seeding is practiced in areas of uncertain distribution of rainfall or inadequate availability of irrigation facilities. Direct seeded rice is gaining momentum in India due to high demand of labour during peak season of transplanting and availability of water for short periods. Herbicides are considered to be an alternative supplement to hand weeding. ${ }^{2}$ Herbicide residue analysis is also important for the food safety.

\section{Material and methods}

Field experiment was conducted during kharif season at Tamil Nadu Agricultural University; Coimbatore to evaluate Metamifop for its residual effect direct seeded rice. The experimental field was situated in the North Western Agro- climatic Zone of Tamil Nadu at 110 North latitude, $77^{\prime}$ East longitude and at an altitude of $426.7 \mathrm{~m}$ above MSL. The normal weather conditions prevailed at the experimental location is briefed here under. A mean annual rainfall of $640 \mathrm{~mm}$ was received in 43 rainy days (mean of 25years). The mean maximum and minimum temperature were $31.5^{\circ} \mathrm{C}$ and $27.2^{\circ} \mathrm{C}$ respectively. The relative humidity was $95 \%$. During the growing season, Rice plants received a rainfall of $407 \mathrm{~mm}$ in 23 rainy days. The mean maximum and minimum temperature were $31.1^{\circ} \mathrm{C}$ and $21.7^{\circ} \mathrm{C}$ respectively. The treatments were Metamifop at $50 \mathrm{~g}$ a.i ha ${ }^{-1}$ as POE at 2-3 leaf stage $\left(\mathrm{T}_{1}\right)$, Metamifop $10 \mathrm{EC}$ at $75 \mathrm{~g}$ a.i ha ${ }^{-1}$ as
POE at 2-3 leaf stage $\left(\mathrm{T}_{2}\right)$, Metamifop $10 \mathrm{EC}$ at $100 \mathrm{~g}$ a.i ha ${ }^{-1}$ as POE at 2-3 leaf stage $\left(\mathrm{T}_{3}\right)$, Metamifop $10 \mathrm{EC}$ at $125 \mathrm{~g}$ a.i ha ${ }^{-1}$ as POE at 2-3 leaf stage $\left(\mathrm{T}_{4}\right)$, Metamifop $10 \mathrm{EC}$ at $50 \mathrm{~g}$ a.i ha ${ }^{-1}$ as POE at 5-6 leaf stage $\left(\mathrm{T}_{5}\right)$, Metamifop $10 \mathrm{EC}$ at $75 \mathrm{~g}$ a.i ha- ${ }^{-1}$ as POE at 5-6 leaf stage $\left(\mathrm{T}_{6}\right)$, Metamifop $10 \mathrm{EC}$ at $100 \mathrm{~g}$ a.i ha ${ }^{-1}$ as POE at 5-6 leaf stage $\left(\mathrm{T}_{7}\right)$, Metamifop $10 \mathrm{EC}$ at $125 \mathrm{~g}$ a.i ha $\mathrm{ha}^{-1}$ as POE at 5-6 leaf stage $\left(\mathrm{T}_{8}\right)$, Metamifop $10 \mathrm{EC}$ at 200g a.i ha ${ }^{-1}$ as POE at 5-6 leaf stage $\left(\mathrm{T}_{9}\right)$. After the harvest of rice, the soil samples were collected for the estimation of herbicide residues. The collected samples were shade dried, powdered and sieved through a $2.0 \mathrm{~mm}$ sieve. Besides, grain and straw samples were also analyzed for herbicide residues by using and High Performance Liquid Chromatography (HPLC).

\section{Method for the Determination of the Metamifop Residues in Rice Extraction}

\section{Sample preparation}

i. Rice grain and straw samples were grinded prior to extraction. Rice straw was cut in to pieces of 0.5 to $1 \mathrm{~cm}$ and then subjected to grinding.

ii. Soil was pounded and sieved to pass through $2 \mathrm{~mm}$ sieve.

\section{Extraction}

Macerate samples (for soil $50 \mathrm{~g}$, for grains, use $20 \mathrm{~g}$ and for straw, use $20 \mathrm{~g}$ ) in a $500 \mathrm{ml}$ conical flask with $40 \mathrm{ml}$ of distilled water for 2 minutes. Shake the macerated samples for 30 minutes in $100 \mathrm{ml}$ of acetonitrile then filter through filter paper. Rinse filters cake twice with $50 \mathrm{ml}$ each of acetonitrile. Concentrate combined filtrates at $40^{\circ} \mathrm{C}$ under reduced pressure. Transfer the concentrated solution to a $500 \mathrm{ml}$ separatory funnel, add $50 \mathrm{ml}$ of water, $50 \mathrm{ml}$ of saturated sodium chloride solution and then partition in $100 \mathrm{ml}$ of ethyl acetate by shaking. Allow phases to separate, and let upper ethyl acetate fraction pass through a bed of anhydrous sodium sulfate into a $300 \mathrm{ml}$ round bottom flask. Re-extract aqueous portion with an additional $100 \mathrm{ml}$ of ethyl acetate and filter organic layer through anhydrous sodium sulfate 
into the same $300 \mathrm{ml}$ round bottom flask. Evaporate organic layers in water bath then dissolve the concentrate in $5 \mathrm{ml}$ of acetonitrile/water $(40 / 60, v / v)$ and labeled "solution A".

\section{Clean-up}

The "solution A" was filtered through Flurosil layer and add $10 \mathrm{ml}$ of hexane/acetone (90/10). Evaporate in water bath. And make up the volume to $5 \mathrm{ml}$ by hexane/ acetone $(90 / 10)$.

\section{Chromatographic conditions}

\begin{tabular}{lll}
\hline Column & $:$ & C 18 - column \\
Mobile phase & $:$ & Acetonitrile/Water $(75 / 25, \mathrm{v} / \mathrm{v})$ \\
UV wavelength & $:$ & $240 \mathrm{~nm}$ \\
Flow rate & $:$ & $1.0 \mathrm{ml} / \mathrm{min}$ \\
Attenuation & $:$ & $2^{4}$ \\
Sample size & $:$ & $15 \mu 1$ \\
Flow rate & $:$ & $1 \mathrm{ml}$ per minute \\
Detector & $:$ & Photo Diode Array \\
Software & $:$ & Class - VP
\end{tabular}

\section{Result and discussion}

The highest concentration of metamifop active substance was determined in soil from plots where it was applied at $200 \mathrm{~g} \mathrm{a.i} \mathrm{ha}^{-1}$ at 5-6 leaf stage $\left(\mathrm{T}_{9}\right)$ and followed by $125 \mathrm{~g}$ a.i ha ${ }^{-1}$ at 5-6 leaf stage $\left(\mathrm{T}_{8}\right)$ and $100 \mathrm{~g}$ a.i ha ${ }^{-1}$ at 5-6 leaf stage $\left(\mathrm{T}_{7}\right)$. Decrease in dose decreases the residue content. This might be due to the lesser degradation of the active substance Kim et al., ${ }^{3}$ At the same rate of application of $125 \mathrm{~g}$ a.i ha ${ }^{-1}$, the concentration of residue varies with the time of application i.e the mean residue of metamifop at post harvest soil was 0.031 and $0.048 \mathrm{ppm}$ respectively in the plots which received metamifop at 2-3 leaf and 5-6 leaf stage. The mean residue concentration varied from 0.005 to $0.075 \mathrm{ppm}$ across different treatments. Lower rates $(50 \& 75 \mathrm{~g}$ a.i ha ${ }^{-1}$ ) of application the metamifop did not have any residue in soil, grain and straw og direct seeded rice (Table 1).

Table I Residue of metamifop ( $\left.\mathrm{mg} \mathrm{kg}^{-1}\right)$ in soil and plant parts of direct seeded rice

\begin{tabular}{|c|c|c|c|}
\hline Treatments & Soil & Grain & Straw \\
\hline $\mathbf{T}_{1}$ - Metamifop $10 \mathrm{EC}$ at $50 \mathrm{~g}$ ai ha- ${ }^{-1}$ as POE & BDL & BDL & BDL \\
\hline $\mathbf{T}_{2}$ - Metamifop $10 \mathrm{EC}$ at $75 \mathrm{~g}$ ai ha-1 as POE & BDL & BDL & $\mathrm{BDL}$ \\
\hline $\mathbf{T}_{3}$ - Metamifop $10 \mathrm{EC}$ at $100 \mathrm{~g}$ ai $\mathrm{ha}^{-1}$ as POE & 0.005 & BDL & $\mathrm{BDL}$ \\
\hline $\mathbf{T}_{4}$ - Metamifop $10 \mathrm{EC}$ at $125 \mathrm{~g}$ ai ha ${ }^{-1}$ as POE & 0.031 & 0.001 & 0.010 \\
\hline $\mathbf{T}_{5}$ - Metamifop $10 \mathrm{EC}$ at $50 \mathrm{~g}$ ai ha- ${ }^{-1}$ as POE & BDL & BDL & BDL \\
\hline $\mathbf{T}_{6}$ - Metamifop $10 \mathrm{EC}$ at $75 \mathrm{~g}$ ai ha- ${ }^{-1}$ as POE & 0.035 & BDL & BDL \\
\hline $\mathbf{T}_{7}$ - Metamifop $10 \mathrm{EC}$ at $100 \mathrm{~g}$ ai ha ${ }^{-1}$ as POE & 0.042 & 0.004 & 0.025 \\
\hline $\mathbf{T}_{8}$ - Metamifop $10 \mathrm{EC}$ at $125 \mathrm{~g}$ ai ha ${ }^{-1}$ as POE & 0.048 & 0.060 & 0.037 \\
\hline $\mathbf{T}_{\mathbf{9}}$ - Metamifop $10 \mathrm{EC}$ at $200 \mathrm{~g}$ ai ha ${ }^{-1}$ as POE & 0.075 & 0.221 & 0.096 \\
\hline
\end{tabular}

( TI to T4 - application at 2-3 leaf stage and T5 to T9 at 5 -6 leaf stage) $\mathrm{PE}$, pre- emergence; $\mathrm{POE}$, post emergence BDL, below detectable level Data not statistically analyzed.
Similar to the soil, the residue of metamifop concentration was higher at higher rates of application in grain and straw and again the concentration detected was varied with the time of application. The highest concentration of metamifop active substance was determined in grain and straw samples from plots where it was applied at $200 \mathrm{~g}$ a.i ha $^{-1}$ at 5-6 leaf stage $\left(\mathrm{T}_{9}\right)$ and followed by $\mathrm{T}_{8}$ and $\mathrm{T}_{7}$ where metamifop was applied at $125 \mathrm{~g}$ a.i and $100 \mathrm{~g}$ a.i ha ${ }^{-1}$ at 5-6 leaf stage and $100 \mathrm{~g}$ a.i and $100 \mathrm{~g}$ a.i ha ${ }^{-1}$ at 5-6 leaf stage. The metamifop concentration varied from 0.001 to $0.221 \mathrm{ppm}$ and 0.01 to $0.096 \mathrm{ppm}$ in grain and straw respectively. The concentration of metamifop was high in grain than in straw. The low concentration of metamifop has no residual effect so it is safer for food grains to consume.

\section{Acknowledgements}

None.

\section{Conflict of interest}

The author declares no conflict of interest.

\section{References}

1. Department of Agriculture and Cooperation. Directorate of economics and statistics; 2008.

2. Rajendra Kumar B. Studies on weed management in anaerobic tolerant rice cultivars under direct wet seeded condition. MSc Thesis, Coimbatore, India: Tamil Nadu Agric Univ; 2003.

3. Kim TJ, Chang HS, Ryu JW, et al. Metamifop: a new post-emergence grass killing herbicide for use in rice. The BCPC International Congress: Crop Science and Technology, 1-2. In: Proceedings of an international congress held at the SECC. Glasgow, Scotland, UK; 2003. 